\title{
Transformative urban railway: Ankara commuter line and lost landscape
}

\author{
Funda Baş Bütüner ${ }^{1}$, Ela Alanyalı Aral ${ }^{1}$, Selin Çavdar ${ }^{2}$ \\ ${ }^{1}$ Department of Architecture, ${ }^{2}$ Department of City and Regional Planning. \\ Middle East Technical University. Ankara, Turkey \\ E-mail: fbutuner@metu.edu.tr, earal@metu.edu.tr, selin.cavdar@gmail.com
}

\begin{abstract}
Being major transportation infrastructure of the 19th and early 20th centuries, the impacts of railways on cities have highly directed urban studies; deforming material edge of cities, encouraging urban extension, forming new territories, and speeding up urban development. However, in recent decades, with newly emerging landscape infrastructure practice, a new idea for a more integrated infrastructure and landscape system has started to be formulated. Railway strips, occurring as territories where solid-void morphology of cities becomes illegible, emerge as generators in the formation of urban green network. Within this framework, Ankara commuter line that mark outs a route approximately 37 kilometers in length in the city, is a remarkable case for a motivating discussion on railway and landscape confrontation. Penetrating the city in east-west direction, the commuter line integrated with a rural landscape-covering orchards, truck gardens and creeks- that was serving as a recreational field for citizens until 1950s. However, the transformative nature of the railway encouraged the development of new urban lands, industrial areas and neighborhoods along its route, and erased the characteristic landscape fabric. The continuous landscape integrated with green, water and railway infrastructure became fragmented covering only some splits of green and water. In this respect, this study dwells on the lost landscape of the commuter line by mapping the fragmented continuity of the railway, green and water infrastructure from 1950's until today to show the limited, but potential interaction of these three systems in the current urban fabric.
\end{abstract}

Keywords: urban railway, urban landscape, Ankara, commuter line, landscape infrastructure.

\section{Introduction}

Railways, conceived as major transportation infrastructure in the dissolvement of the material city borders, introduced a new speed that encouraged the (re)formation of urban territories after the 19th century. Increased accessibility with the development of the railways transformed rural lands into suburban neighborhoods and triggered the urban expansion. This makes railway lines prevailing in the development of urban form and also in the formation of urban fabric. However, their challenging spatial manifestation -being both generator and eradicator- makes them notable also for urban landscape studies. Being generators, they have encouraged the formation of new urban districts; while they might be also named as eradicators for erasing rural landscapes. Therefore, their spatiality cannot be easily comprehended through the well-known figure-ground mapping and reading. Their shifting role certainly requires an in-depth study that dwells on their changing spatiality in different times and in different scales.

By this means, this study intends to discuss railway-city confrontation through discovering 
the transforming landscape fabric along SincanKayaş commuter line in the city of Ankara. Being a peculiar example of the urban railways, Sincan-Kayaş commuter line demarcates a line approximately 37 kilometers in length in eastwest direction within the city. Commuter line, once penetrating a rural landscape intertwined with creeks, orchards, truck gardens and plantation areas, now pierces densely built urban fabric of Ankara. Hydrography and vegetation that was forming and characterizing the rural and spontaneous landscape along the commuter line, have been entirely erased since 1950's, when rapid urbanization process started. The interplay among the railway, water lines and green areas that was forming a filigreed landscape morphology and fabric, were interrupted with the development of new land use patterns. This process ended up with the fragmentation of the landscape fabric compromising covered or canalized water lines and remaining patches of green as reminiscent of a previously integrated system.

\section{Transportation Infrastructure and Landscape: Towards an Integrated System}

Recently emerged discussions and practices through landscape urbanism have reminded the disregarded hybrid urban spaces to the urban agenda. Post-industrial lands and urban infrastructures are sites where landscape urbanism has introduced predominant strategies to moderate the complex relation between nature and city, rather than seeing them as two opposing and binary milieus (Waldheim, 2002). Herein, urban railways, demarcating a territory in cities, might be discussed as key (infra)structures where the relation between city and nature might be (re) discovered through landscape strategies.

Indeed, recent rapprochement between infrastructure and landscape in the urban landscape literature might find its conceptual origin in landscape milieu. Infrastructure as an artificial ecology highly integrated with landscape that intrinsically manage the flow of goods, people, animals, energy and resources before the construction of engineered infrastructure. As mentioned by Carlson (2013),
"Landscape is inherently infrastructural: it mediates, produces, facilitates and transports. As a network of infrastructural function and flow, landscape ...becomes the operative platform of human existence; where landscape exists, so does infrastructure" (Carlson, 2013). This inherited quality doubtlessly approves the need for a filigreed landscape fabric that puts infrastructure as a generator, rather than peripheral armature. Transportation infrastructures, by manipulating the surface, trigger urban development; "Infrastructure prepares the ground for future building and creates the condition for future events. Its primary modes of operation are; the division, allocation, and construction of surfaces; the provision of services to support future programs; and the establishment of networks for movement, communication, and exchange" (Allen, 1991, p.54).

Besides their impact on the (de)formation of urban macroform, grounding a network that penetrates urban surface, transportation infrastructures also emerge as "collective spaces" in expanding cities (Wall, 1999). Being "both a response to, and generator of" horizontal urban expansion, infrastructures are more than backdrops of urban development. They serve as interfaces where we communicate with larger systems (Bélanger, 2013). Their multi-scale character delineates a network that highly contributes to urban and landscape fabric. Transportation infrastructures provide macro scale relations and flows while forming pointlike spaces that serve for providing transition and communication among different systems and scales. Compared with other mode of transportation infrastructures, railway lines are more integrated with human scale spaces; such as stations. Within the railway network, stations might be identified as nodes where larger continuous systems meet and interact with the local ones. As Bertolini and Spit (1998) propose, apart from defining a node, having a particular spatial typology and impact area, stations might be also recognized as places; "...harbor district, airport city, or station neighborhood", which "reflect a particular kind of interaction with the area, the direct surroundings and the urban region in which these modes are located" (Bertolini \& Spit, 1998, p.15). 
In this prominence, railways, being bold, strict, wide, continuous, linear infrastructures, identify particular settings within the urban morphology. Decoding railways through three major components of urban morphological studies, stated by Moudon (1997) as form, resolution and time, might generate motivating discussion on their spatiality. Differing than the essential physical elements of urban form -buildings and their related open spaces, plots or lots, and streets- (Moudon, 1997) railways generate atypical relations and spaces within the city that cannot be decoded through solid-void /figure-ground mapping. Their confrontation and interaction with(in) the urban fabric offers diverse settings that might be explored in different scales and at different resolutions such as; "rural landscape-railway", "city-railway", "neighborhood/districtrailway", "station-railway".

Another aspect of the railway lines is their transformative quality that generates continuing land use and spatial changes all along their neighboring environment. The timeline and pattern of the transformation is critical, not only for understanding the spatial history of the railway, but also for the development of future urban landscape strategies. As argued by Tatom (2006), cities should discover new modes of relation with transportation lines and expose them as urbanistic opportunities rather than technical necessities; "from utility to amenity, from infrastructure to urbanism" (Tatom, 2006, p.181).
Regarding this theoretical framework, the main focus of this study, Ankara commuter line, offers a motivating discussion on the lost urban landscape and its possible recall for an integrated landscape infrastructure. Understanding the commuter line at different levels of resolution, might expose both its challenging position and possible contribution for the city of Ankara; a connector line in east-west direction / a barrier that split neigborhoodscape; a generator for new land use development / a destructive force for rural landscape. All these states expose railway as an operative line with shifting dispositions and perceptions within the urban timeline of Ankara.

\section{Changing Landscape Fabric along the Sincan-Kayaş Commuter Line}

Emerging as transformative lines in the cities, impacts of railways on the (de)formation of the urban fabric have been undoubtedly visible in the urban history of Ankara. Commuter line, following the extension of the AnkaraBaghdad railway infrastructure to Kayaş -east of the city- started to operate in 1928. First journeys between the city center and Kayaş was for recreational purposes with a restricted schedule, rather than serving for inner city transportation. (Emiroğlu \& Uzmay, 2013, p. 46). In following years, with the emergence

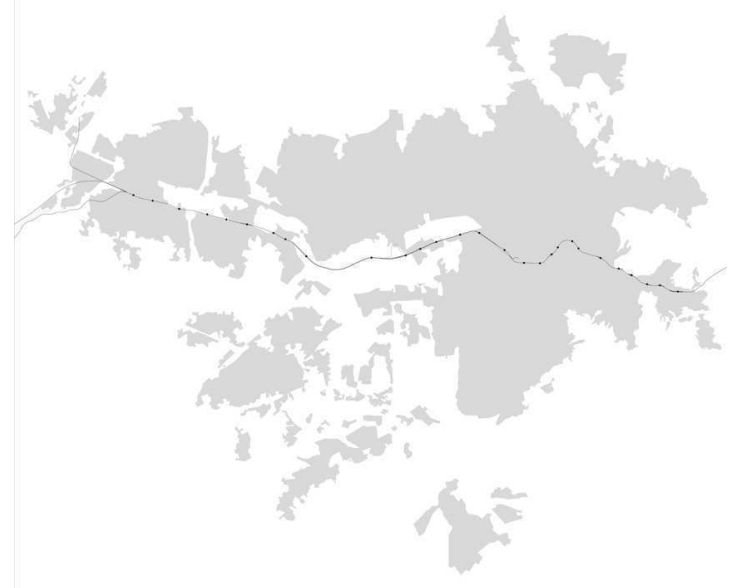

Figure 2.

Figure 1.

Sincan - Kayaş commuter line and urban macroform in 1950s.

\section{Sincan - Kayaş commuter line and urban} macroform in 2010s. 
of regularly scheduled passenger carriage, the commuter line became the first public urban transportation of the Republican Period Ankara by connecting the urban center -Yenişehir- to the suburban districts and villages of the city (Tekeli, 2010). Rural lands where commuter line facilitated the daily access, started to emerge as new suburban neighborhoods of the city and were replaced with the built fabric. With the expansion of the urban surface, commuter line that was connecting the city center with the suburban neighborhoods has emerged as an urban railway wedged within the city (Figure 1-2).

Today, penetrating the city in east - west direction -between Kayaş and Sincan-, the line compromises 28 stations that serve for inner city public transportation ${ }^{1}$. This makes Sincan-Kayaş commuter line a connection stripe within the city. On the other hand, by demarcating a bold track with its rigid railway infrastructure, commuter line interrupts the access and continuity in north-south direction. Particularly, horizontal stratification along the commuter line caused by accompanying linear structures and spaces -multi-lane roads, elevated junctions, spontaneous vegetation and linear greens- creates an urban fissure (Baş Bütüner, 2010) that marks commuter line as a barrier zone.

Apart from the fissure generated by the commuter line, the encounters between railway and its neighboring landscape and built fabric are also critical for decoding the railway morphology and spatiality. Atatürk Forest Farm ${ }^{2}$ lands, industrial areas, housing districts/neighborhoods, military zones, urban transformation sites, creeks and unoccupied lands have been some of the fragments aligned along the commuter line. This makes commuter line "an element of order" (Waldheim, 2011) that intersects and confronts with various landscapes and urban milieus rather than being single purpose transportation infrastructure. Discovering the shifting and multi-dimensional mode of relation between landscape and commuter line is critical for future landscape infrastructure strategies.

Ankara commuter line offers a characteristic case by identifying a territory where three infrastructures -transportation, green and water- coexist. However, the interplay among green areas, creeks and railway line that was once forming a landscape fabric, was highly damaged after 1960s. The railway zone was mainly regulated by transportation-based strategies and planning approaches rather than spatial concerns. This formed a sharp disruption / disconnection between the commuter line and its surrounding environment and designated railway as an isolated line.

The above mentioned two arguments -changing spatiality and shifting role of the commuter line- have affected the landscape fabric that might be easily mapped in the urban timeline of Ankara. Taking the city center as the reference node, the east part of the commuter line -between Demirlibahçe and Kayaş- was aligned with Hatip Creek and intermingled with a green fabric covering vineyards, orchards and truck gardens almost for eight kilometers. This green strip served as prevalent recreational field of the city until the construction of the first squatter houses in Mamak district in 1960s (Özaslan, 2014). In 1970s, the landscape fabric of the east was mostly erased and replaced by squatter neighborhoods (Şenyap1lı, 1970; Öncü, 1979) (Figure 3).

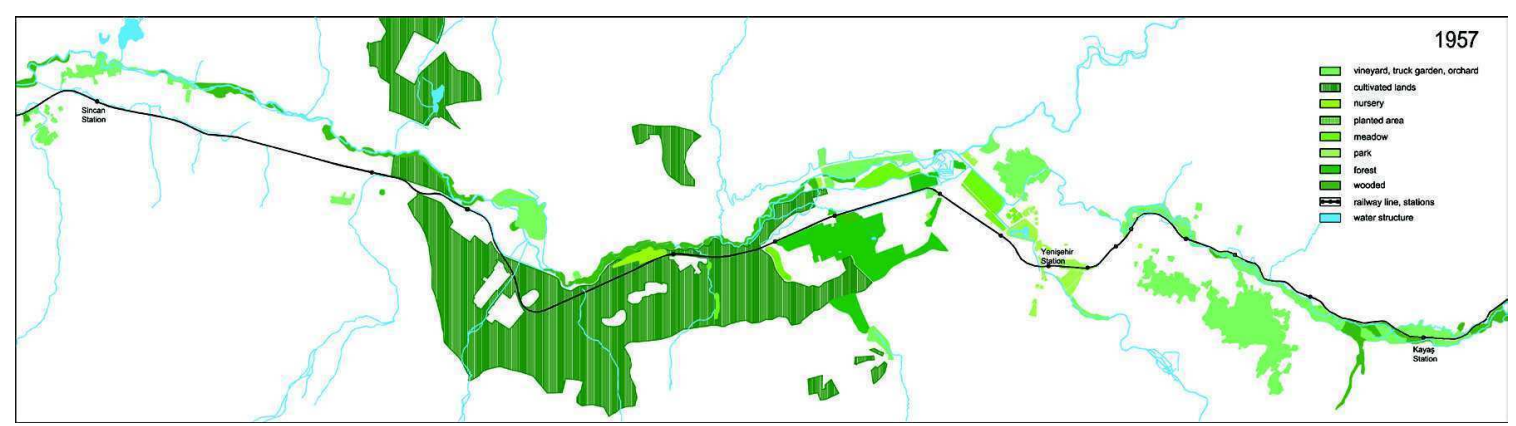

Figure 3.

Coexistence of three infrastructures; green, water and railway (based on 1957 Ankara Map) 
Unlike the dense green of east, landscape fabric along the west part of the commuter line was loose. The flat lands of the west were mostly designated for industry, public institutions and military use. Only Atatürk Forest Farm lands, serving as productive and recreational landscape of the capital city in republican period, were delineating a considerable green surface at that part of the railway stripe in 1957 Ankara map (Figure 4).

The macro scale landscape enfolding the commuter line in 1957 map has drastically changed in following years. Cultivated lands of Atatürk Farm Forest and green stripe vineyard, truck gardens and orchards- of the east which were forming a rural landscape have shrunk and were replaced by built fabric. The dramatic loss of the green and water interrupted the intermingled landscape along/ of the commuter line and created a solitaire transportation infrastructure within the city. As mapped in 2013 landscape fabric diagram, continuous green infrastructure along the commuter line in 1950's was replaced by small scale neighborhood parks that were constructed to reclaim some of the leftover interface spaces between the railway and the city. Similarly, creeks were tamed to prevent flooding and water infrastructure reappeared in the form of fragmented canalized water line. This transformation has triggered the loss of the characteristic landscape fabric -green, water and railway infrastructure- and also revoked macro scale contribution of the commuter line in the construction of a continuous landscape infrastructure.

In this respect, promising coexistence of the railway and allied landscape has to be discussed through the varying confrontation between these two milieus at different levels of resolution. For this purpose, aside from discussing the transforming landscape of the railway stripe, diverse patterns of the landscape fabric might be also decoded through the maps of Ankara. Changing land classification and legend of the 1957 and 2013 Ankara maps clearly expose the distinctive qualities of the earlier landscape and its dramatic loss in time. As represented in Table 1, landscape fabric along the railway was compromising variety in topographic morphology, vegetation, occupation and water elements $^{3}$ in 1957 map. When compared with 2013 map, 1957 map clearly exposes the diversity and complexity of the landscape fabric, covering cemetery, forest, plantation areas, nursery, truck garden, vineyard, orchard, woodland, deciduous trees and creeks, and their reduction both in size and in surface diversity. Although some reminiscences of the former landscape fabric -deciduous trees, canals, plantation areas, park- partially exist today along the commuter line, they are lacking of integration. Transformation triggered by urban development and fragmentation caused by enlarged roads eliminated the diversity and produced a built fabric divided by the railway line. However, the new fabric transmits several landscape space typologies that might contribute to the formulation of an integrated landscape infrastructure along the commuter line;

Linear Patches. Rural landscape, experiencing double transformation, was invaded first by squatter houses by 1960 s and later replaced by apartment blocks, as seen in Mamak and Gülveren cases. Current urbanized scenery of Mamak and Gülveren totally erased

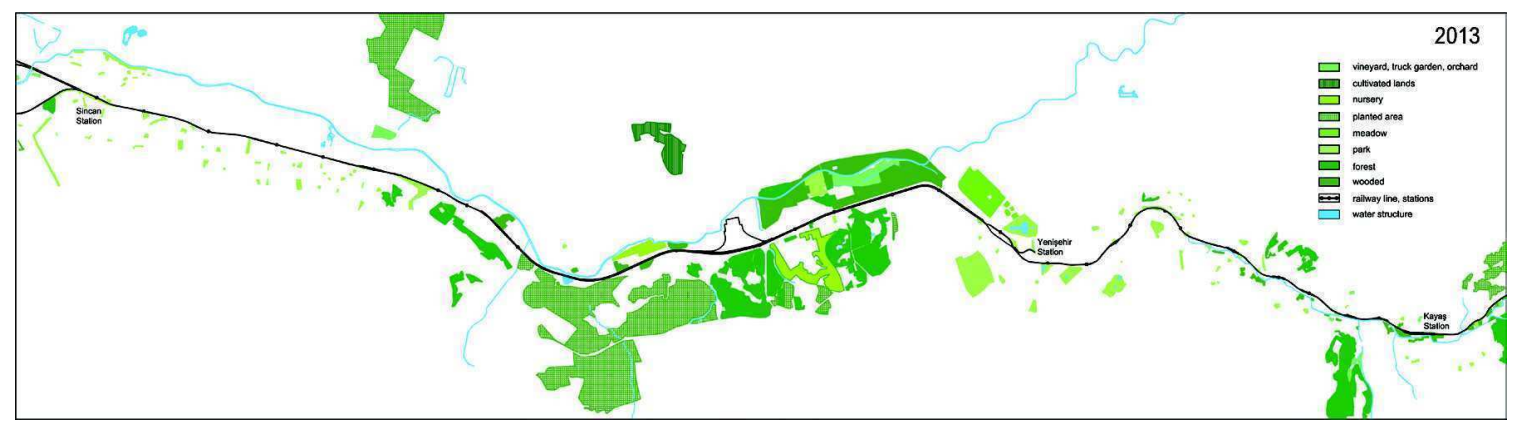

Figure 4.

Fragmented landscape along the commuter line (based on 2013 Ankara Map) 
Table 1.

Changing Landscape along Sincan-Kayaş Commuter Line

Landscape Fabric (1957)
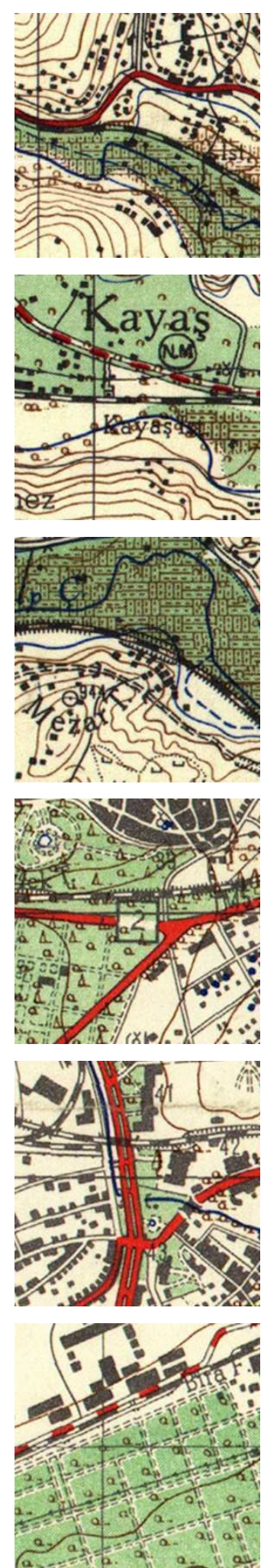

\section{Mamak}

Railway

Hatip Creek,

Truck garden

Deciduous trees

Kayaş

Railway

Hatip Creek

Truck garden

Orchard

Deciduous trees

\section{Gülveren}

Railway

Hatip Creek

Cemetery

Truck garden

\section{Kurtulus}

Railway

Forest

Sıhhiye

Railway

İncesu Creek

Urban park

Atatürk Forest Farm

Railway

Nursery

Vineyard

Ankara Creek
Landscape Fragments (2013)

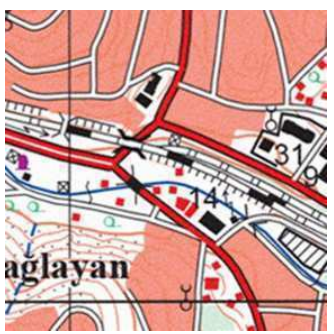

Mamak

Railway

Canalized Hatip Creek

Deciduous trees

Linear neighborhood park

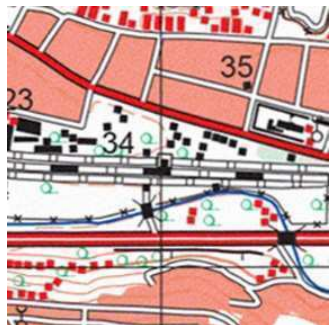

Kayaş

Railway

Canalized Hatip Creek

Deciduous trees

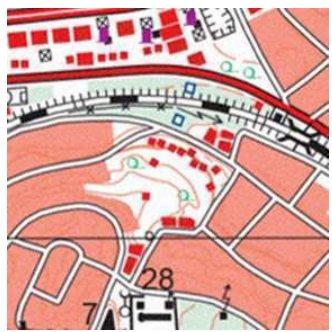

\section{Gülveren}

Railway

Deciduous trees

Plantation area

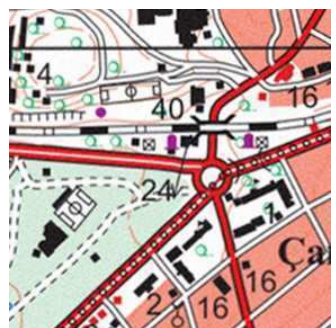

\section{Kurtuluș}

Railway

Deciduous trees

Park

\section{Sıhhiye}

Railway

Deciduous trees

Park

\section{Atatürk Forest Farm}

Railway

Nursery

Deciduous trees 
the productive and recreational characteristic landscape. In both cases, today, the railway line accompanied either by linear greens with spontaneous vegetation or linear neighborhood parks. However, discontinuous character of the linear green does not contribute to form an integrated landscape fabric.

Landscape Reminiscences. Atatürk Forest Farm that partially keeps today its territorial boundaries along the commuter line, lost its characteristic landscape with the appropriation of agricultural and recreational lands for different purposes. However, the farm still retains some reminiscences of the Republican Period's cultural landscape that convey great potential for a possible continuous landscape system along the commuter line.

Unoccupied Terrains. Despite the urbanized scenery of the railway zone, several unoccupied vast lands are still present along the commuter line. As appears in Kayaş, vacant lands with spontaneous vegetation and canalized creek, might perform as reserve areas for the construction of a landscape infrastructure.

Urban Greens. Compared with the other parts, some fragments along the commuter line were also in urban character in 1957, as seen in Kurtuluş and Sihhiye cases. Although these greens mostly keep their boundaries, they lost some of their landscape quality due to the fragmentation and partial transformation.

\section{Conclusion}

The morphology and spatiality of the urban railways expose peculiar conditions in cities. Considering landscape infrastructure approach and practice, urban railways have gained a critical position in the development of landscape strategies. They have emerged as one of the key urban components to moderate complex relation between nature and city, rather than being single purpose transportation armatures. The promising integration of railway and landscape, being two opposing milieus, triggered the establishment of new urban landscape forms and relations.

In this prominence, Sincan-Kayaş commuter line in Ankara represents a distinctive case of urban railways. The presence of three infrastructures-green, water and transportationdisplays a spectacular scene which necessitates an in-depth examination of the landscape fabric in different time and resolution. Intermingled landscape, covering vineyards, orchards, truck gardens, cemeteries, plantation areas and creeks in 1957 map, has been dramatically destroyed and fragmented with the construction of large scale transportation infrastructures and expansion of urban surface. However, commuter line still demarcates an important reference track for the creation of a continuous urban landscape fabric in the city of Ankara. Currently existing landscape typologies -linear patches, landscape reminiscences, unoccupied terrains and urban greens- along the railway might be considered as potential grounds to recreate variety in topographic morphology, vegetation, occupation and water elements. In this way, aside from having a critical review on the changing spatiality and lost landscape along the railway, it will be also possible to develop several spatial strategies to recall previously integrated landscape infrastructure.

\section{Acknowledgments}

This article is based on a scientific research project entitled "Demiryolunun Peyzaj ve Kentsel Tasarım Unsuru Olarak Potansiyelinin Tespiti ve Tasarım İlkelerinin Geliştirilmesi: Sincan-Kayaş Banliyö Hattı" and was financed by Middle East Technical University (20152016). Project Coordinator: Funda Baş Bütüner Team Members: Ela Alanyalı Aral, Selin Çavdar.

\section{Notes}

1 Since 2016 July, Sincan-Kayaş commuter line is under construction for the implementation of Başkentray Project that intends to improve transportation capacity of the railway. The project covers an extensive improvement of the technical infrastructure with new lines and stations.

2 Atatürk Forest Farm (AOÇ), established on $52.000 .000 \mathrm{~m} 2$ of land, is an integrated and comprehensive landscape project that 
intended to introduce modern agricultural and industrial production techniques, as well as to create a recreational and social milieu in early republican period. The farm generated a cultural landscape from the infertile lands of the early republican capital city, Ankara, where rural and urban cultural practices were serving in an interplay. Although, today, the boundaries of Atatürk Forest Farm enormously fragmented and shrank, the farm still expose a considerable territory having unquestionable potential in the generation of a future urban landscape ecosystem. (Kaçar 2011; Çavdar 2014)

3 For further discussion on landscape and its representation see Cartographic Grounds by J. Desimini and C. Waldheim; "The terrestrial ground has multiple physical components: its topographic morphology, its surface material, and its occupation or use. To depict the ground is to describe all of these. Land classification departs from the representation of terrain to describe occupation of the land: cultural and agronomic land uses, vegetation and the material characteristics of the earth's surface. Land-use maps call out the actual and possible uses of lands; they are explanatory and projective" (Desimini\&Waldheim, 2016, p.113).

\section{References}

Allen, S. (1999) 'Infrastructural Urbanism', in Allen, S. (ed.) Points and Lines: Diagrams and Projects for The City (Princeton Architectural Press, New York) 40-89.

Baş Bütüner, F. (2010) 'Urban Fissure: Reconceptualization of the Land Walls within the Urban Milieu of İstanbul', unpublished $\mathrm{PhD}$ thesis, Middle East Technical University, Turkey.

Bélanger, P. (2012) "Landscape Infrastructure: Urbanism Beyond Engineering" in S. N. Pollais, D. Schodek, A.Georgoulias and S.J. Ramos (Ed.) Infrastructure Sustainability and Design (Routledge, London) 276-315.

Bertolini, L. and Spit, T. (1998) Cities on Rails (Routledge, London).

Carlson, D. (2013) 'The Humanity of Infrastructure: Landscape as Operative Ground' Scenario Journal 03 (http:// scenariojournal.com/article/humanity-ofinfrastructure/) accessed 11 February 2017.

Çavdar, S. (2014) 'AOÇ’nin Dönüşüm Süreci ve Nedenleri', Mimarlık Dergisi 377 (http:// www.mimarlikdergisi.com/index.cfm?sayfa $=$ mimarlik $\&$ DergiSayi $=391 \&$ RecID $=3380$ ) accessed 20 May 2017.

Desimini, J. and Waldheim, C. (2016) Cartographic Grounds (Princeton Architectural Press, New York).

Emiroğlu, K., Uzmay, Ü. (2013) Demiryolu Ansiklopedisi (TCDD Gelişim Vakfı Yayınları, Ankara).

Kaçar, D. (2011) 'A Unique Spatial Practice for Transforming The Social and Cultural Patterns: Atatürk Forest Farm in Ankara' METU Journal of the Faculty of Architecture 28:1, 165-178.

Moudon, A.V. (1997) 'Urban Morphology as an Emerging Interdisciplinary Field' Urban Morphology (1997)1, 3-10.

Öncü, E. (1979) 'Ulaşım Türlerinin Kent Yapısına Etkileri: Tarihsel Gelişim ve Ankara Batı Gelişmesinde Demiryolunun Rolü' unpublished master thesis, Middle East Technical University, Turkey.

Özaslan, M. (2014) Ankara'nın “Kahtanesi”ydi Kayaş ve Mamak' İdeal Kent Dergisi, 01(11), 288-299.

Şenyapılı, Ö. (1970) Ankara 70. Mimarlık Dergisi, 04, 39.

Tatom, J. (2006) 'Urban Highways and the Reluctant Urban Realm', in C. Waldheim (Ed.). The Landscape Urbanism Reader (Princeton Architectural Press, New York) 179-196.

Tekeli, İ. (2010) Kent İçi Ulaşım Tarihi Yazıları (Tarih Vakfı Yurt Yayınları, İstanbul).

Waldheim, C. (2011) 'Reading the Recent Work of SWA' in C. Waldheim, Y. Hung, J. Czerniak, A. Geuze, A. Robinson, M. Skjonsberg (Eds.) Landscape Infrastructure: Case Studies by SWA (Birkhauser Basel) 8-13.

Waldheim, C. (2002) "Landscape Urbanism: A Genealogy" Praxis Journal no. 4, 10-17.

Wall, A. (1999) 'Programming the Urban Surface' in J.Corner (Ed.) Recovering Landscape (Princeton Architectural Press, New York) 232-249. 